\title{
Language teaching and learning as a transdisciplinary endeavour
}

\section{Multilingualism and epistemological diversity}

\author{
Anthony J. Liddicoat \\ Centre for Applied Linguistics, University of Warwick
}

Language teaching and learning is commonly considered as a research discipline that resides within the field of 'applied linguistics', at least in the way the field is conceptualized by English-speaking academia. However, if we consider language teaching and learning as practice, this fit is not as neat as it at first might appear. Teaching, learning and using an additional language is complex and multifaceted; it involves languages, cultures, learning, communication, identities, etc., which in turn are situated academically within a host of disciplines. Research in language teaching and learning is therefore transdisciplinary in the sense that multiple disciplines can provide different lenses through which to understand the same phenomena and to build new understandings of the object of interest. Moreover, as a field in which languages and cultures are inherently brought into contact, language teaching and learning is also at an intersection between disciplines that are conceptualized and developed differently in different languages and academic traditions. For example, 'language teaching' as a disciplinary area does not map well onto its French translation equivalent 'didactique des langues'. These interactions across academic traditions therefore represent an oftenunacknowledged form of transdisciplinarity. This contribution will examine how language teaching and learning can be informed by a transdisciplinary perspective in both these senses. In particular, it will focus on the idea of language learning from an intercultural perspective to examine how multiple disciplines and different disciplinary traditions contribute to shaping understanding of the field; it will also consider some of the challenges of bringing multiple disciplines to bear on this understanding.

Keywords: academic cultures and traditions, language teaching and learning, applied linguistics, didactique des langues, multilingualism in research 


\section{Transdisciplinarity and language teaching and learning}

Language teaching and learning as a central focus of applied linguistics is not so much a discipline or sub-discipline as an area of investigation that is understood and researched from many disciplinary and sub-disciplinary perspectives. This disciplinary plurality has been long recognized. For example, Savignon (1991, p. 265) argued that Communicative Language Teaching "can be seen to derive from a multidisciplinary perspective that includes, at least, linguistics, psychology, philosophy, sociology, and educational research", while Corbett (2003) argued for a need to expand the disciplinary base on which language teaching draws. This plurality however has tended to invoke contributions from multiple disciplines as a juxtaposing of multiple domains of knowledge, that is, as multidisciplinarity (Frodeman, 2014). However, the issue that faces language teaching and learning is not simply one of a collective multidisciplinarity (multiple disciplines investigating different aspects of a phenomenon) but requires a synthesizing of perspectives to understand the phenomenon, an epistemological holism rather than an epistemological plurality, and a transcendence of disciplinary boundaries. This is what Nicolescu (1996) calls transdisciplinarity, an approach which is between, across and beyond disciplines - 'ce qui est à la fois entre les disciplines, $\dot{a}$ travers les différentes disciplines et au delà de toute discipline (p. 27, emphasis in original). This paper will explore some of the issues involved in the development of transdisciplinarity in language teaching and learning and consider in particular how the inherent multilinguality of the field provides a particular context in which to understand the transdisciplinary possibilities.

Research and practice in language teaching and learning presents particular issues for understanding transdisciplinarity as a phenomenon in applied linguistics. Many scholars understand transdisciplinarity as an interaction between disciplines in the form of a dialogue between specialists in particular paradigms to create multidimensional responses to the complexity of phenomena being researched (Nicolescu, 1996). This way of thinking has been common in thinking about applied linguistics as a transdisciplinary field. For example, for the Douglas Fir Group (2016), transdisciplinarity in Second Language Acquisition is understood as a synthesizing of researchers' different theoretical positions and ways of working in SLA to create a more holistic and less polarized understanding of the ways languages are acquired. Such forms of transdisciplinarity locate the transdisciplinary within groups of researchers, either working in collaboration or independently, with some synthesizing activity occurring to bring together the contributions of individuals. However, transdisciplinarity may also involve the integration of insights from different disciplines in the work of a single individual, although this conceptualization is less well developed in the literature on 
transdisciplinarity. In discussing the transdisciplinary individual, Augsburg (2014) largely positions the individual within a discipline, but with openness to learn from the perspectives of others and to work collaboratively with others from other disciplinary backgrounds. The individual researcher in transdisciplinarity is thus 'disciplined', and transdisciplinarity is understood ultimately as a collaborative endeavour across and beyond disciplines.

In the area of language education, however, there has been an emergence of the idea of language educators and researchers as transdisciplinary individuals (Byrd Clark, 2016; Scarino \& Liddicoat, 2016). The argument for the idea of the transdisciplinary individual stems basically from a growing awareness of the complexity of languages and their use on the one hand and of complexity of language learning and teaching the on the other. The idea that language and its use are equivalent to knowledge of grammar and vocabulary, along with some pragmatic rules of use, has been increasingly challenged (e.g. Liddicoat \& Scarino, 2013; McConachy, 2018). Language knowledge and language use has come to be seen as multifaceted and multi-layered involving culturally contexted meaning making practices, translanguaging, translating, multimodality, sociolinguistic variability, etc. and ultimately requiring not just the ability to make meaning but also to understand the meaning-making process itself (e.g. García \& Li Wei, 2014; Kramsch, 2011; Liddicoat, 2014, 2016a; Stein, 2004). Language learning and teaching is thus not just language focused. It requires teaching and learning that goes beyond language itself requiring engagement with theories of learning from outside SLA and applied linguistics and drawing on work in the wider field of education (Byrd Clark, 2016; Liddicoat, in press; Scarino \& Liddicoat, 2016). For these reasons, the idea of the language educator or researcher as anchored only in one discipline or sub-discipline and drawing on the expertise of others from other disciplines or sub-disciplines is highly problematic as it orients only to a partial understanding of the phenomenon in focus. A crossing of disciplinary and subdisciplinary boundaries is thus central to work in language education (Byrd Clark, 2016). The focus of language education is not simply language; it is a confluence of language, culture, intercultural capabilities, learners, learning, teachers, pedagogy, curriculum, policy, etc. Different facets of language teaching and learning require different theory, methods, and literatures.

The idea of the transdisciplinary individual working within a synthesis of disciplinary perspectives is one that is both attractive and problematic within contemporary academia. It is attractive because it is a concrete instantiation of the breaking down of disciplinary boundaries, which has become a hallmark of much thinking about contemporary research (e.g. Augsburg, 2014; Frodeman, 2014; Douglas Fir Group, 2016). At the same time, it is problematic because academic work is still strongly framed by disciplinarity and the disciplined researcher. 
Transdisciplinarity of both types is potentially problematic in modern conceptions of the academy. Institutional constraints may require the work of transdisciplinary teams to be disaggregated into disciplinary contributions rather than being seen as a whole. This is especially the case in research evaluation activities such as the Research Excellence Framework (REF) in the UK or Excellence in Research for Australia (ERA) in Australia, where, in spite of lip-service to ideas such as 'interdisciplinarity' or 'transdisciplinarity', disciplines and discipline boundaries are enshrined as central to ways of determining the quality and effectiveness of research practice (Ade-Ojo \& Ogunleye, 2017; Woelert \& Millar, 2013). The work of transdisciplinary individuals is largely unrecognized and may not be viewed as transdisciplinary at all because of the prevailing world view that sees individuals as being located in disciplines and transdisciplinarity as being solely understood as collaborative research.

\section{A multilingual perspective on transdisciplinarity}

The basic currency of language education is multilingualism and language educators and researchers act within a fundamentally multilingual context. This multilingualism is manifested in many ways. The 'content' of the field is essentially multilingual; the key focus is the development of multilingual abilities and any language can potentially be the focus of research and practice, although it is most commonly associated with English (Liddicoat, 2016b). Moreover, research and practice in language education are conceived, produced and communicated in multiple languages, each with their own historically rooted academic traditions. Working multilingually thus involves, not only working across languages, but also across academic traditions, which each have their own socially, culturally, linguistically and historically situated epistemological categories.

The following discussion will consider the consequentiality of a multilingual perspective for the linguistic, cultural and epistemological diversity of language teaching and learning as a field of research and practice and for how we can understand transdisciplinarity in applied linguistic research. It will do this by considering the work of a bilingual research network (ReN), the AILA ReN Intercultural mediation in language and culture teaching and learning/La médiation interculturelle en didactique des langues et des cultures. This research network is made up of members who work within two broad linguistic and academic traditions - English-speaking and French-speaking, although its members share much more diverse linguistic backgrounds and engagements. The network has a rigorous policy of plurilingualism; all meetings and the work of the network are done in the two major languages of the group, often with additional support 
from other languages (Liddicoat \& Zarate, 2016). Working collaboratively across languages and academic traditions in this group revealed that, while epistemological framings of the research field in different academic traditions may superficially appear to be the same, they are in fact supported by very different epistemological bases. The various linguistic and academic traditions can therefore be considered as instances of different disciplinary contexts, and a synthesis across these contexts is required.

\subsection{Example 1: Framing the disciplinary field}

While all members of the ReN view themselves as working within the field of language teaching and learning, the way that the disciplines are segmented varies across the two linguistic and academic traditions. For those participants working within the English-speaking world, the base discipline is understood as applied linguistics. The French-speaking participants reject a connection with linguistique appliquée, which they view as a very different discipline from their own, and identify with didactique des langues. All three terms represent interdisciplinary fields of language-based study, but the scope of each is different.

It is a commonplace of scholarship in applied linguistics to observe that the field is difficult to define (see for example Brumfit, 1997; Cook, 2002; Davies, 2007; Grabe, 2002; Widdowson, 2005). The reasoning for this has been that applied linguistics permits a broad frame of activities and that this breadth makes definition difficult. Attempts at definition tend to identify an area of focus for applied linguistics work, which is developed in such broad, macro-level terms as

theoretical and empirical investigation of real-world problems in which language is a central issue

(Brumfit, 1997, p. 93)

problems in the world in which language is implicated

(Cook, 2002, p. 5)

a practice-driven discipline that addresses language-based problems in real world contexts.

(Grabe, 2002, p. 10)

This broad characterization means that applied linguistics in the English-speaking world reaches beyond the field of language teaching and learning and connects with other ways of approaching language as a social and communicative reality.

Linguistique appliquée is the direct translation equivalent of English 'applied linguistics' but the French term has a more narrowly conceived disciplinary base than applied linguistics (Véronique, 2009) and resembles Widdowson's (1980, 2000) idea of 'linguistics applied' as a narrowly focused, linguistics-driven discipline in contrast with a more transdisciplinary 'applied linguistics'. The issue of the relevance of linguistique appliquée for the teaching and learning of languages has 
been contested in the French academic tradition since the 1970s, with Coste (1975) going so far as to state that the discipline could only be relevant if it abandoned its relationship with linguistics. In reaction to the criticisms of linguistique appliquée, a new discipline began to emerge in the 1970s with a specific focus on language education, didactique des langues, sometimes also called didactique des langues et des cultures (Bailly, 1997; Liddicoat, 2009; Puren, 2005; Véronique, 2009). For theorists such as Bailly (1997) la didactique des langues is an enterprise which is driven not by a discipline such as linguistics, but rather by classroom practices and realities on which subsequent theorizations are developed; that is, it is an attempt to theorize practice rather than to employ theory to explain practice. This new discipline had a specific focus on teaching and learning, but eschewed linguistics as a main contributing domain, drawing instead on fields such as education, sociology and anthropology. Didactique des langues is thus located within a transdisciplinary field, itself located within a broader field of education (didactique) rather than within a specifically language-related field, such as linguistics.

On the surface, the terminologies here would seem to represent little more than a problem of translation in which English 'applied linguistics' represents an umbrella under which linguistique appliquée and didactique des langues could be grouped. However, the solid boundaries that have merged in the French academic tradition mean that the two have come to shape their own epistemologies, methodologies and theories and have drawn on different discursive resources to construct these. Collectively, the two French disciplines do not represent a divided version of English 'applied linguistics' but rather two independent fields of study which have developed relatively independently of 'applied linguistics', especially in the case of didactique des langues. Each of the three ways of conceptualizing the epistemological space permit certain discursive possibilities and constrain others to the extent that a collaboration between applied linguists and didacticiens des langues requires openness to new epistemological possibilities and ways of constructing the field of enquiry.

\subsection{Example 2: Intercultural mediation/Médiation interculturelle}

The core focus of the AILA ReN is the concept of 'intercultural mediation/médiation interculturelle' and this core focus has proved to be the ground for a transdisciplinary encounter between applied linguistics and didactique des langues.

The discussions of the ReN have identified five key processes that constitute intercultural mediation when considered from the perspective of the teaching and learning of languages and cultures. These five key processes are (Liddicoat \& Zarate, 2016, pp. 32-34): 
Reflexivity: Reflexivity is the process of revisiting one or more previous experience or life history to distance oneself from this lived experience and develop awareness of phenomena connected to diversity opening up multiple possible perspectives and interpretations where previously only one had been seen. The process attempts to take into account the social and cultural context of these perspectives.

\section{Connecting: Involves creating and} understanding new meaning as the result of interacting with others, making connections between one's own and other ways of thinking and meaning, and considering the consequences of such new connections for one's own way of interacting with others.

Interpreting: Involves seeking meaningfulness in experiences of linguistic and cultural diversity, creating and recognizing meaning in communication, understanding the process of meaning making, and what each person brings to the act of making and interpreting meaning and seeking ways to explain meanings to others.

Re-establishing meaning: To restore, re-establish or reconstruct meaning after a breakdown to create a better understanding in a context of intercultural conflict and/or confrontation within or between individuals within a given society or between societies.

\section{Managing tensions: Managing tensions} involves recognizing the existence of real or possible tensions, choosing strategies appropriate to institutional or other contexts that can range from forbidding conflict to managing crises and negotiation, and focusing either on cognition or emotion. The aim is to preserve or reconstruct relationships, the central capabilities being attentive listening and the ability to accept conflict based on an institutional or contextual analysis.
Réflexivité: On appelle réflexivité le processus qui consiste à revisiter une ou des expériences antérieures ou des parcours pour mettre à distance ce vécu et prendre conscience des phénomènes liés à l'altérité entraînant les multiplicités des points de vue et des interprétations possibles là où une seule a été initialement perçue. Ce processus tente de prendre en compte les conditions sociales et culturelles de ces points de vue.

Établir les liens: Implique la création et la compréhension de nouvelles significations suite aux interactions avec les autres, faire des liens entre sa façon et d'autres façons de penser et de faire sens, et considérer les conséquences de telles connexions dans sa propre façon d'interagir avec les autres.

Interprétation: Implique la recherche de faire sens lors d'expériences de diversité linguistique et culturelle, créer et reconnaître le sens dans la communication, comprendre le processus de signification, ce que chacun apporte dans l'action de faire sens et chercher les moyens d'expliquer ces significations aux autres.

Restauration de sens : Rétablir, réhabiliter, et/ ou reconstruire du sens après rupture pour une meilleure compréhension dans un contexte interculturel de conflit et/ou de confrontation intra et/ou inter individuel dans une société donnée ou entre sociétés données.

Gérer les tensions : Gérer les tensions consiste à reconnaître l'existence de tensions réelles ou potentielles. Choisir des stratégies adaptées aux contextes institutionnels ou autres, pouvant aller de l'interdit du conflit à la gestion de crises, en passant par la négociation, en privilégiant plutôt le cognitif ou l'émotionnel. L'objectif est la préservation ou la reconstruction du lien, les compétences centrales étant à partir d'une analyse institutionnelle ou contextuelle la qualité d'écoute, et la capacité d'accueil du conflit. 
These processes were identified collectively as key elements of a shared understanding of mediation. However, in the course of the group's discussions, it emerged that the two traditions approached the idea of mediation in very different ways. Of the five processes, four (reflexivity, interpreting, re-establishing meaning and managing tensions) emerged as elements of mediation that are common to both traditions, although they receive different emphases in the different traditions. However, even here, some differences appeared in how each tradition understood mediation that reflect some key epistemological differences.

The most significant of these was in the ways the two groups positioned the element 'managing tensions'. For participants working in the French language tradition, this was a central concept, while for those working within the English language tradition it was considered more peripheral. For those working within didactique des langues, teaching was seen as a central focus and so much of the thinking about mediation had focused on the role of the teacher. The teacher as mediator was seen as someone who needed to intervene in that problems emerged in intercultural communication that emerged in the social realities of the classroom. This perception was further strengthened because a focus of the researchers was on French classes for immigrants in which mixed groups of students often experienced problems of intercultural understanding among themselves and the teacher's role as the mediator of such conflicts was a central concern. For participants working within the English language tradition, the starting assumptions were different. The starting point was much more frequently placed on the learner rather than the teacher and mediation was understood as an activity of learning. The teacher as mediator was thus thought of more as a facilitator of learning than as a manager of conflict (Kohler, 2015). The prime focus in the English-speaking tradition was on learners as mediators of their own learning and on their experiences of languages and cultures. Managing tensions was not thought to be central in the role of learners in the classroom, although it was acknowledged that learners certainly do experience such tensions. This raised a central question that had dominated discussions within the ReN: who is the mediator?

The key element that created most difficulties in discussions was the idea of 'connecting', which initially participants working in the French language tradition did not see as a form of mediation at all, but which for participants working in the English language tradition was seen as a central concept. Connecting was presented within a Vygotskian theory of learning as the mediational work that occurs between a learner and a more knowledgeable other to allow learning to happen. It was also seen as the process by which languages and cultures, and their roles in meaning-making, were brought into relationship by or for the learner (Kohler, 2015). For participants working in the French language tradition, this view of mediation was difficult as it did not seem to be based on an idea that mediation 
was an activity that happened where meaning and hence social relationships had broken down. Thus, a further key question for the ReN was 'what is mediation?'.

The ideas of the mediator and mediation are central to the entire understanding of 'intercultural mediation/mediation interculturelle' that the group was working with and the emergence of tensions between understandings represented different epistemologies, each with its own possibilities and assumptions. 'Mediation' proved therefore not to be a simple issue that all researchers had in common but rather an epistemological challenge that needed to be further addressed in working between English-language applied linguistics and French-language didactique des langues.

One way to work through this challenge has been to consider the epistemological history of the term 'mediation' as it was used within the group and one key part of this was the ways that the work of the Russian psychologist Lev Vygotsky has been read and understood within the two epistemological traditions. Vygotsky argues that learning is guided by culture and interpersonal communication and that higher mental functions develop through social interactions with more competent others. Through interactions, a person comes to learn the habits of mind of a culture, including spoken and written language, and other forms of symbolic knowledge through which people derive meaning and construct knowledge (Vygotsky, 2005, 1978).

While Vygotskian ideas of learning are present in both English-speaking and French-speaking traditions, the ways that Vygotsky's work has been taken on has shaped the theory in different ways in each academic culture. Of particular relevance for the thinking of the ReN is the translation of Vygotsky's Russian посредники (literally 'intermediaries'), which is usually translated as 'mediation' in English and 'médiation' in French, but which has been further shaped by its incorporation into each tradition (c.f. Liddicoat \& Zarate, 2009). The idea in Russian is of language as a tool that comes between experience and thought and thus constructs interpretation of experience and learning for it. This key idea of the Vygotskian theory of learning is often referred to in English as 'cultural mediation' (e.g. Hausfather, 1996; Moll, 2014). Vygotsky argued for a dialectical relationship between thought and language in which language played the role of a mediational tool that shaped thought, interpretation and learning. However, in Vygotsky's work, the term cultural mediation/cultural mediator (культурныц посредник) does not appear to be used, although the association of mediation and culture is quite strong. The term "cultural mediation" is thus a product of the movement of Vygtoskian ideas into the English language academic domain. The term посредники, however, has a different trajectory in French language academia, where it more usually is found as 'médiation pédagogique' (e.g. Chappaz, 1996), reflecting Vygotsky's relationship between mediation and learning rather 
than his association between mediation and culture. In its French form, it has developed associations that are relevant to the word pédagogie, which tends to have a narrow sense of teaching techniques. Médiation pédagogique is thus understood as the technical interventions that teachers make to support learning. Thus, the academic traditions arising in French and English on the basis of Vygotsky's work have given different emphases to the original Russian ideas. In reality, what can be seen at work here are three different epistemological strands - Russian, French and English - each of which has its own understanding and patterns of discursive use that shapes the disciplinary terrain.

In order to understand mediation, the ReN has had to articulate the various starting points that have informed thinking and to consider critically how the movement of ideas across linguistic and cultural horizons has shaped perceptions of the phenomenon under investigation. Exploring such issues has allowed participants from each tradition to reconceptualize mediation as a feature of teaching and learning and then develop a synthesis across the contributing epistemological traditions. Such a synthesis provides new insights that reveal gaps in existing conceptualizations and the need to refine thinking and practice as two disciplinary traditions are brought into relationship.

\section{Conclusion}

The discussion in this paper shows that superficial similarities between academic traditions may mask underlying epistemological differences because equivalent terminologies can represent differences in conceptualization. These differences emerge often in the movement between languages as the process of translation involves not just a reformulating of the terms but also an interpretation and negotiation of the concepts which are being translated (Liddicoat, 2016a; Scarino, 2016). Multilingual ways of working thus have the potential to bring to the surface the complex disciplinarities that underlie the conceptual and terminological resources of academic discourse.

The epistemological universe is not simply a set of differing categories within an academic system, but different systems constructing different epistemological universes both within and outside the academy (de Sousa Santos, 2007, 2009). There is therefore a need to engage not only with epistemologies of one's own linguistic and epistemological tradition but also with other linguistically and culturally different traditions; transdisciplinarity must have room for other epistemological systems, developed and communicated through a range of languages. Encounters between epistemological differences can lead to a sense of the incompleteness of disciplines/disciplinary knowledge as a way of understanding a particular reality. 
This incompleteness is generative as it can lead to new insights into the substance and practice of research: "La "synthèse" entre A et non-A est plutôt une explosion d'immense énergie' [the "synthesis" between $\mathrm{A}$ and not- $\mathrm{A}$ is rather an explosion of immense energy] (Nicolescu, 1996, p. 18)

Working with and across epistemological traditions is ultimately a political act in that it is an engagement with power structures that exist within epistemologies, academic cultures and global flows of knowledge. Academic work is conducted against a backdrop of historical, political and social processes that have constructed some epistemologies as superior to others (Rooney, 2011; van Binsbergen, 2007). The hierarchy of epistemologies has historically placed North Atlantic epistemologies in the position of superiority and this position has been justified in terms of an "internal epistemological superiority: its rationality, its unique logic of argumentation, its universal language, its methods which guarantee objectivity, etc." (van Binsbergen, 2007, p. 302). More recently, however, patterns of publication have increasingly given emphasis to epistemologies communicated in English (Curry \& Lillis, 2004; Lillis \& Curry, 2010; Salager-Meyer, 2008). Thus, 'mainstream' journals have become synonymous with English-language journals and these journals are seen as disseminating high quality research suited for consumption by international academia and therefore as having epistemological superiority (López-Navarro et al., 2015). Publication in these journals is rewarded in ways that publishing in other languages is not both within and outside academic institutions (Curry \& Lillis, 2004) reinforcing the subordination of other epistemologies to those created and communicated in English. Rooney (2011) argues that patterns of subordination of epistemologies and the resulting exclusion of knowledges create "patterns of ignorance" that are "systematically produced and reinforced by mainstream perspectives that still insist - explicitly or otherwise - that particular groups of knowers, particular forms of knowledge, understanding, and insight, or particular topics and questions about human knowledge... are beyond the pale of epistemology" (p. 13). Monolingual academic practices may therefore close off possibilities for transdisciplinary thinking to produce a homogenization of epistemology and so of disciplinarity. Engagement with epistemologies that are created and communicated in a range of languages is an intervention into the power relations and prevailing ideologies of contemporary academic practice and the linguistic construction of contemporary academic work. Language education and applied linguistics research operate within the prevailing linguistic and epistemological ideologies of contemporary academia and may even model a monolinguistic, monocultural and mono-epistemological practices. One consequence of the prevailing ideology of English language publications' epistemological superiority has been that publications in other languages are less likely to be used and cited, even in contexts where multilingual practices would be expected (Liddicoat, 2016b). 
Multilingual, transdisciplinary academic practice is not only relevant for researchers' conceptualizations and theorizing, it is also a practical problem for language educators. Differing epistemologies become operationalized in teaching resources, professional learning programmes and other support for teachers. Thus, a foreign language teacher may have to negotiate between differing epistemologies: those that originate in the languages and cultures of the context in which they teach and those that originate in the language(s) they teach. Such teachers may be called upon to choose between epistemological differences or to attempt to reconcile them in their classroom practice. Moreover, they will usually be called on to do this in classrooms characterized by a diversity of languages, cultures and epistemologies among the students they teach.

Language education is inevitably at an intersection of linguistic, cultural and epistemological possibilities and so highlights the need to include multilingual practice and openness to the diverse epistemologies created and communicated through languages in understanding the transdisciplinary individual. This individual needs to be conceptualized not only as someone who is open to others' perspectives and disciplinary stances (c.f. Augsburg, 2014) but also someone who is open to working with ideas created and expressed in other languages. The transdisciplinary individual thus needs to be an active participant in multilinguality, either through their own personal multilingualism or through their willingness to work with multilingual others to engage with ideas developed and communicated in diverse languages. This then involves particular ways of working between, with and through languages that seek to explore instances of disconnection or miscomprehension between languages to understand the epistemological roots of research conducted in different languages, readiness to engage with the practices of informal, local translation as a form of academic dialogue, and willingness to engage in contexts where comprehension of other researchers may be neither immediate nor assured.

Such transdisciplinary work has the potential to provide a corrective to ethnocentric (usually Anglo-centric) practices of dissemination of ideas and hierarchization of epistemologies (Guo \& Beckett, 2007; Holliday, 2005; Kumaravadivelu, 2016; Phillipson, 1992). The forms of academic work being discussed in this paper are dialogic; they reject uncritical importing of particular practices and theories from an external academic context and the valuing of one academic tradition above others. As a transdisciplinary endeavour, working multilingually considers each academic tradition as having a contribution to make and aims at a reciprocal transformation of thought and practice in all of the epistemological traditions involved. In this way, genuinely multilingual practice can represent a way to engage productively with epistemological diversity (see Pennycook, this volume). 


\section{Notes}

Coordinators: Martine Derivery and Anthony Liddicoat. Members: Angela Scarino, Barbara Pizziconi, Chan Wai Meng, Daniel Chan, Elli Suzuki, Geneviève Zarate, George Alao, Jacqueline Breugnot, Jamila Guiza, Julie Byrd-Clark, Kwee Nyet Chin, Mariko Himeta, Michelle Kohler, Noriko Iwasaki, Sasiwimol Klayklueng, Seo Won Chi, Stella Cambrone-Lasne, Yukiko Saito.

\section{References}

Ade-Ojo, G., \& Ogunleye, J. (2017). Interdisciplinarity and the new REF agenda. International Journal of Multidisciplinary Comparative Studies, 4(1-3), 3-5.

Augsburg, T. (2014). Becoming transdisciplinary: The emergence of the transdisciplinary individual. World Futures, 70(3-4), 233-247. https://doi.org/10.1080/02604027.2014.934639

Bailly, D. (1997). Didactique de l'anglais (1) Objectifs et contenus de l'enseignement. Paris Nathan. Brumfit, C. (1997). Theoretical practice: Applied linguistics as pure and practical science. AILA Review, 12, 18-30.

Byrd Clark, J. (2016). Transdisciplinary approaches to language learning and teaching in transnational times: Introduction to the special issue. L2 Journal, 8(4), 3-19.

Chappaz, G. (1996). Comprendre et construire la médiation. Spirale. Revue de recherches en éducation, 17, 7-24. https://doi.org/10.3406/spira.1996.1915

Cook, G. (2002). Applied linguistics. Oxford: Oxford University Press.

Corbett, J. (2003). An intercultural approach to English language teaching. Clevedon: Multilingual Matters. https://doi.org/10.21832/9781853596858

Coste, D. (1975). La méthodologie de l'enseignment des langue maternelle et seconde: État de la question. Études de linquistique appliquée, 18, 5-21.

Curry, M. J., \& Lillis, T. (2004). Multilingual scholars and the imperative to publish in English: Negotiating interests, demands, and rewards. TESOL Quarterly, 38(4), 663-688. https://doi.org/10.2307/3588284

Davies, A. (2007). An introduction to applied linguistics: From practice to theory (2nd ed.). Edinburgh: Edinburgh University Press.

de Sousa Santos, B. (2007). Conhecimento e transformação social: Para uma ecologia dos saberes. Somanlu: Revista de Estudos Amazônicos, 7(1), 175-189.

de Sousa Santos, B. (2009). A non-occidentalist west?: Learned ignorance and ecology of knowledge. Theory, Culture \& Society, 26(7-8), 103-125.

https://doi.org/10.1177/0263276409348079

Douglas Fir Group. (2016). A transdisciplinary framework for SLA in a multilingual world. The Modern Language Journal, 100(S1), 19-47. https://doi.org/10.1111/modl.12301

Frodeman, R. (2014). Sustainable knowledge: A theory of interdisciplinarity. Houndmills, UK: Palgrave Macmillan. https://doi.org/10.1057/9781137303028

García, O., \& Li Wei. (2014). Translanguaging: Language, bilingualism and education. New York: Palgrave Macmillan. https://doi.org/10.1057/9781137385765 
Grabe, W. (2002). Applied linguistics: An emerging discipline for the twentieth century. In R. B. Kaplan (Ed.), Oxford Handbook of Applied Linguistics (pp. 3-12). New York: Oxford University Press.

Guo, Y., \& Beckett, G. H. (2007). The hegemony of English as global language: Reclaiming local knowledge and culture in China. Convergence, 40(1/2), 117-132.

Hausfather, S. J. (1996). Vygotsky and schooling: Creating a social context for learning. Action in Teacher Education, 18(2), 1-10. https://doi.org/10.1080/01626620.1996.10462828

Holliday, A. (2005). The struggle to teach English as an international language. Oxford: Oxford University Press.

Kohler, M. (2015). Teachers as mediators in the foreign language classroom. Bristol, UK: Multilimgual Matters. https://doi.org/10.21832/9781783093076

Kramsch, C. (2011). The symbolic dimensions of the intercultural. Language Teaching, 44(3), 354-367. https://doi.org/10.1017/S0261444810000431

Kumaravadivelu, B. (2016). The decolonial option in English teaching: Can the subaltern act? TESOL Quarterly, 50(1), 66-85. https://doi.org/10.1002/tesq.202

Liddicoat, A. J. (2009). « La didactique » et ses équivalents en anglais: terminologies et cadres théoriques dans la circulation des idées. Le Français dans le monde: Recherches et applications, 46, 33-41.

Liddicoat, A. J. (2014). Pragmatics and intercultural mediation in intercultural language learning. Intercultural Pragmatics, 11(2), 259-277. https://doi.org/10.1515/ip-2014-0011

Liddicoat, A. J. (2016a). Intercultural mediation, intercultural communication and translation. Perspectives: Studies in Translatology, 24(3), 347-353.

https://doi.org/10.1080/0907676X.2014.980279

Liddicoat, A. J. (2016b). Multilingualism research in Anglophone contexts as a discursive construction of multilingual practice. Journal of Multicultural Discourses, 11(1), 9-24. https://doi.org/10.1080/17447143.2015.1086361

Liddicoat, A. J. (in press). Teaching languages from an intercultural perspective: Rethinking the nature of learning. In R. Arber, M. Weinmann, \& J. Blackmore (Eds.), Innovative languages education. New York: Routledge.

Liddicoat, A. J., \& Scarino, A. (2013). Intercultural language teaching and learning. Chichester: Wiley-Blackwell. https://doi.org/10.1002/9781118482070

Liddicoat, A. J., \& Zarate, G. (2009). La didactique des langues face à la circulation internationale des idées. Le Français dans le monde: Recherches et applications, 46, 9-13.

Liddicoat, A. J., \& Zarate, G. (2016). Intercultural mediation in language and culture teaching and learning/ La médiation interculturelle en didactique des langues et des cultures. International Journal of Applied Linguistics, 26(1), 132-134. https://doi.org/10.1111/ijal.12145

Lillis, T. M., \& Curry, M. J. (2010). Academic writing in a global context: The politics and practices of publishing in English. London: Routledge.

López-Navarro, I., Moreno, A. I., Burgess, S., Sachdev, I., \& Rey-Rocha, J. (2015). Why publish in English versus Spanish?: Towards a framework for the study of researchers' motivations. Revista Española de Documentación Científica, 38(1), 1-16. https://doi.org/10.3989/redc.2015.1.1148

McConachy, T. (2018). Developing intercultural perspectives on language use in foreign language learning. Bristol: Multilingual Matters.

Moll, L. C. (2014). L.S. Vygotsky and education. New York: Routledge.

Nicolescu, B. (1996). La transdisciplinarité: Manifeste. Paris: Editions du Rocher.

Phillipson, R. (1992). Linguistic Imperialism. Oxford: Oxford University Press. 
Puren, C. (2005). Didactique des langues cultures : Entrées libres. Cahiers pédagogiques, 437, $58-71$.

Rooney, P. (2011). The marginalization of feminist epistemology and what that reveals about epistemology 'proper'. In H. E. Grasswick (Ed.), Feminist epistemology and philosophy of science: Power in knowledge (pp. 3-24). Dordrecht: Springer.

https://doi.org/10.1007/978-1-4020-6835-5_1

Salager-Meyer, F. (2008). Scientific publishing in developing countries: Challenges for the future. Journal of English for Academic Purposes, 7(2), 121-132.

https://doi.org/10.1016/j.jeap.2008.03.009

Savignon, S. J. (1991). Communicative language teaching: State of the art. TESOL Quarterly, 25(2), 261-278. https://doi.org/10.2307/3587463

Scarino, A. (2016). Reconceptualising translation as intercultural mediation: A renewed place in language learning. Perspectives: Studies in Translatology, 24(3), 470-485.

https://doi.org/10.1080/0907676X.2015.1022192

Scarino, A., \& Liddicoat, A. J. (2016). Reconceptualising learning in transdisciplinary languages education L2 Journal, 8(4), 20-35.

Stein, P. (2004). Representation, rights, and resources: Multimodal pedagogies in the language and literacy classroom. In B. Norton \& K. Toohey (Eds.), Critical pedagogies and language learning. Cambridge, New York: Cambridge University Press.

https://doi.org/10.1017/CBO9781139524834.006

van Binsbergen, W. (2007). The underpinning of scientific knowledge systems: epistemology or hegemonic power? The implications of Sandra Harding's critique of North Atlantic science for the appreciation of African knowledge systems. In P. J. Hountondji (Ed.), La rationalite, une ou plurielle? (pp. 294-327). Dakar: CODESRIA \& UNESCO.

Véronique, D. (2009). La linguistique appliquée et la didactique des langues et des cultures: Une polémique française au coeur d'un débat international. Le Français dans le monde: Recherches et applications, 46, 42-52.

Vygotsky, L. S. (2005). Мыиление и речь. Moskow: Smysl. (Original work published 1934).

Vygotsky, L. S. (1978). Mind in Society. The Development of Higher Psychological Processes (M. Cole, Trans.). Cambridge, MA: Harvard University Press.

Widdowson, H. G. (1980). Models and fictions. Applied Linguistics, I(2), 165-170. https://doi.org/10.1093/applin/l.2.165

Widdowson, H. G. (2000). On the limitations of linguistics applied. Applied Linguistics, 21(1), 3-25. https://doi.org/10.1093/applin/21.1.3

Widdowson, H. G. (2005). Applied linguistics, interdisciplinarity, and disparate realities. In P. Bruthiaux, D. Atkinson, W. G. Eggington, W. Grabe, \& V. Ramanathan (Eds.), Directions in applied linguistics (pp. 12-25). Clevedon, UK: Multilingual Matters.

Woelert, P., \& Millar, V. (2013). The 'paradox of interdisciplinarity' in Australian research governance. Higher Education, 66(6), 755-767. https://doi.org/10.1007/s10734-013-9634-8 